\title{
Menakar Nilai Pendidikan Karakter Acara Televisi pada Anak Usia 6-8 Tahun
}

\author{
Atiqa Sabardila1, Markhamah², Zainal Arifin ${ }^{3}$, Hari Kusmanto ${ }^{\natural}$, Lathifah Nurul \\ Hidayah $^{5}$, Anita Dewi Kurniasari ${ }^{6}$, Duwi Saputro ${ }^{7}$ \\ Pendidikan Bahasa Indonesia, Universitas Muhamadiyah Surakarta $(1,2,3,4,5,6,7)$ \\ DOI: $10.31004 /$ obsesi.v6i1.875
}

\begin{abstract}
Abstrak
Media pendidikan karakter tidak hanya terbatas pada buku teks, karya sastra, maupun ungkapan hikmah. Media pendidikan yang dapat digunakan selain yang telah disebutkan adalah acara televisi sebagai media pendidikan karakter. Artikel ini bertujuan mendeskripsikan nilai-nilai pendidikan karakter yang terdapat dalam program acara televisi yang diminati anak-anak Sekolah Dasar (SD) kelas rendah (usia 6-8 tahun). Menggunakan pendekatan deskriptif kualitatif. Data penelitian ini adalah nilai-nilai pendidikan karakter yang terdapat dalam program acara yang diminati anak-anak SD. Sumber data penelitian ini adalah program acara televisi yang diminati anak-anak SD. Data-data penelitian ini dikumpulkan dengan menggunakan metode kuesioner, observasi dan dilanjutkan dengan teknik catat. Analis data penelitian ini menggunakan metode padan referensial atau analisis isi. Hasil penelitian ini menunjukkan terdapat sepuluh nilai pendidikan karakter dalam program acara televisi yang diminati anak-anak SD. Hal tersebut didasarkan pada nilai pendidikan karakter dan nilai sosial budaya yang terkandung dalam acara tersebut.
\end{abstract}

Kata Kunci: pendidikan karakter; program acara televisi; anak usia 6-8 tahun

\begin{abstract}
This article aims to describe the values of character education contained in television programs that are of interest to elementary school (SD) children. The approach used in this research is descriptive qualitative. The data of this research are the values of character education contained in programs that are of interest to elementary school children. The data source of this research is a television program that is of interest to elementary school children. The research data were collected using a questionnaire method, observation and followed by note-taking techniques. This research data analysis using a referential matching method or content analysis. The results of this study indicate that there are ten values of character education in television programs that are of interest to elementary school children. The ten-character values include (1) social care, (2) honesty, (3) peace-loving, (4) nationalism, (5) curiosity, (6) discipline, (7) creative, (8) hard work, (9) responsibility, and (10) religion. This is based on the character education values and sociocultural values contained in the event. In addition, it is also seen from the minimal content of violent scenes.
\end{abstract}

Keywords: character education, television program, early childhood

Copyright (c) 2021 Atiqa Sabardila, Markhamah, Zainal Arifin, Hari Kusmanto, Lathifah Nurul Hidayah, Anita Dewi Kurniasari, Duwi Saputro

$\triangle$ Corresponding author:

Email Address : harikusmanto.ums@gmail.com (Surakarta, Indonesia)

Received 4 November 2020, Accepted 5 Januari 2021, Published 9 April 2021 


\section{PENDAHULUAN}

Persoalan pendidikan karakter anak-anak Sekolah Dasar (SD), utamanya kelas rendah yaitu rentang usia 6-8 tahun perlu mendapatkan perhatian dan sentuhan dari berbagai pihak, seperti keluarga, kaum pendidik, maupun masyarakat secara umum. Hal tersebut dikarenakan nilai-nilai pendidikan dapat dikatakan berhasil apabila diinternalisasikan dalam kehidupan sehari-hari. Oleh karena itu, perlu adanya berbagai kerja sama dalam membangun anak-anak SD usia 6-8 tahun supaya memiliki karakter yang baik.

Pendidikan karakter anak-anak SD usia 6-8 tahun masih menjadi permasalahan tersendiri yang belum dapat terselesaikan. Berikut ini beberapa masalah pendidikan karakter yang terjadi di SD usia 6-8 tahun: pertama, pendidikan karakter di SD usia 6-8 tahun belum didasarkan pada prinsip-prinsip pendidikan yang benar. Kedua, belum adanya grand desain pendidikan karakter di setiap sekolah masing-masing. Ketiga, pelaksanaan pendidikan karakter di wilayah Jawa Timur belum mengembangkan nilai kehidupan, seperti kecintaan, penghargaan, kedamaian, kerja sama, kepatuhan, demokrasi, belum seluruhnya menjadi kepedulian dalam praktik pendidikan karakter di SD usia 6-8 tahun. Keempat, tatanan pendidikan karakter yang diciptakan di SD usia 6-8 tahun masih didominasi kepala sekolah dan guru. Kelima, praktik pembelajaran yang kurang menghargai kemanusiaan manusia (Sa'dun et al., 2014). Hal tersebut menunjukkan bahwa pendidikan karakter di SD usia 6-8 tahun belum dipraktikkan secara optimal. Oleh karena itu, perlu adanya upaya memberikan bimbingan dan praktik baik kepada anak-anak untuk berperilaku yang mencerminkan karakter yang baik dalam kehidupan sehari-hari. Hal tersebut dapat dimulai dari lingkungan terkecil tempat anak tinggal, yakni keluarga melalui acara televisi yang ditonton anak-anak. Alasannya mengapa televisi karena televisi memiliki keunggulan dengan media lainnya. Keunggulan televisi di antaranya adalah daya jangkau yang lebih luas, selektivitas dan fleksibel, fokus, kreativitas dan efek, prestise, dan waktu tertentu (Andrianto, 2018).

Penelitian yang telah dilakukan dan berkaitan dengan penelitian menunjukkan acara televisi sinetron memberikan dampak terhadap perkembangan perilaku sosial anak (Novita et al., 2017). Dampak yang diakibatkan oleh acara televisi sinetron tersebut mempengaruhi perilaku sosial anak terutama pada pola perilaku sosial anak terhadap teman sebaya dan orang dewasa, yaitu perilaku anak melebihi perilaku usia anak 5 tahun, hal ini disebabkan oleh perilaku imitasi anak saat menonton televisi.

Penelitian mengenai pengaruh acara televisi terhadap perkembangan anak-anak dilakukan Rohani (2017) dengan fokus pembahasan pada pengaruh positif dan negatif acara televisi terhadap perkembangan anak-anak. Dampak positif acara televisi terhadap perkembangan anak-anak adalah meningkatkan perkembangan anak pada berbagai aspek seperti anak lebih komunikatif; imaginatif; dan aktif. Adapun dampak negatif acara televisi bagi perkembangan anak adalah penurunan prestasi belajar anak karena terlalu sering menonton televisi.

Program acara televisi menyajikan berbagai acara dan berbagai genre yang tidak semua cocok untuk anak-anak SD usia 6-8 tahun. Hal tersebut sesuai dengan yang dinyatakan Lin, Cherng, Chen, Chen, \& Yang (2015) bahwa anak-anak yang berlebihan menonton televisi dapat merusak perkembangan anak. Namun, ada juga program acara yang cocok untuk anak SD usia 6-8 tahun dan bahkan potensial untuk dijadikan sebagai media sosialisasi nilai-nilai pendidikan karakter bagi anak-anak SD usia 6-8 tahun. Hal tersebut dapat dipahami karena kekuatan televisi dapat meningkatkan antusiasme kepedulian, pengetahuan bahkan keinginan khalayak melalui setiap adegan, tayangan, gambar, suara, dan pesan-pesan yang disajikan (Kusuma \& Darmastuti, 2019). Berdasarkan berbagai program acara televisi yang tidak semua cocok untuk anak-anak maka perlu adanya bimbingan orang tua dalam menonton program acara televisi.

Anak-anak perlu mendapatkan bimbingan dalam menonton televisi karena acara yang disajikan tidak semuanya cocok untuk usia anak-anak. Setidaknya acara televisi yang ditawarkan memiliki dua manfaat positif dan negatif (Sari, Nariyah, \& Wihayati, 2019; 
Darmastuti, Purnomo, Utami, \& Yulia, 2019). Manfaat positif acara televisi dapat diperoleh apabila anak-anak mendapat bimbingan dari orang tua dalam menonton acara televisi.

Manfaat positif acara televisi apabila digali lebih lanjut mampu dijadikan sebagai media, model, dan percontohan pendidikan karakter bagi anak-anak. Pada dasarnya acara televisi memiliki manfaat yang positif tanpa menampik manfaat negatif acara televisi. Adapun Manfaat positif acara televisi di antaranya: seperti pendidikan, kreativitas, dan pengetahuan penggunaan dan mengoperasionalkan komputer (Rohani, 2017). Hal tersebut juga diperkuat Kostyrka-Allchorne, Cooper, \& Simpson (2017) bahwa menonton acara televisi berkonten pendidikan berkualitas tinggi pada masa prasekolah mampu meningkatkan keterampilan akademis dasar.

Adapun ekses negatif seperti banyaknya waktu yang digunakan untuk menonton televisi, pengaruh kekerasan dari acara televisi, dan tingkah laku agresif terhadap pendidikan (Tarigan et al., 2016). Selain itu, dalam jangka panjang anak-anak yang waktunya lebih banyak digunakan untuk menonton televisi dapat memicu gangguan mental, seperti depresi dan rasa cemas (McAnally et al., 2019). Berdasarkan hal tersebut dapat disimpulkan bahwa televisi memiliki dampak positif dan negatif.

Karakter adalah apa yang dipikirkan, diucapkan, dan dilakukan oleh seseorang dalam kehidupan sehari-hari dan menjadi kebiasaan. Karakter merupakan nilai-nilai dalam diri seseorang yang unik dan baik yang direalisasikan dalam perilaku (Sabakti, 2018). Jadi, karakter bukanlah suatu konsep teoretis saja, melainkan perilaku seseorang. Hal tersebut sesuai dengan yang dinyatakan Suryanto (2017) bahwa karakter merupakan cara berpikir dan berperilaku yang menjadi kekhasan seseorang dalam hidup dan bekerja sama, baik dalam lingkup keluarga, masyarakat, bangsa, dan negara.

Adapun nilai pendidikan karakter yang dapat dipilih dan dikembangkan di sekolah minimal sejumlah 49 karakter, nilai karakter ini bersumber dari Character Firts sebagai berikut: (1) kewaspadaan; (2) perhatian; (3) kesediaan; (4) kebajikan; (5) keberanian; (6) kehati-hatian; (7) rasa peduli yang tinggi; (8) kesiapan hati; (9) kreativitas; (10) bersifat yakin; (11) rasa hormat; (12) dapat diandalkan; (13) berketepatan hati: (14) kerajinan; (15) kecerdasan; (16) kebijaksanaan; (17) ketabahan; (18) antusias; (19) keyakinan; (20) keluwesan; (21) pemberi maaf; (22) dermawan; (23) lemah lembut; (24) pandai berterima kasih; (25) sifat menghormati orang lain; (26) keramahtamahan; (27) kerendahan hati; (28) inisiatif; (29) keriangan; (30) keadilan; (31) kesetiaan; (32) kelembutan hati; (33) kepatuhan; (34) kerapian; (35) kesabaran; (36) kepercayaan; (37) ketepatan waktu; (38) kecerdikan; (39) pertanggung jawaban; (40) pelindung; (41) kontrol diri; (42) kepekaan; (43) ketulusan hati; (44) ketelitian; (45) sikap berhemat; (46) toleran; (47) kejujuran; (48) sifat bijak; dan (49) kearifan (Samani \& Hariyanto, 2017).

Berdasarkan uraian penelitan yang relavan yang telah disajikan di atas terlihat dominasi peneliti terdahulu membahas dampak dan pengaruh acara televisi bagi perkembangan anak-anak. Dampak dan pengaruh yang ditemukan adalah dampak positif maupun dampak negatif yang ditimbulkan dari acara tersebut. program acara televisi memiliki nilai-nilai pendidikan karakter yang potensial untuk dijadikan sebagai media sosialisasi nilai-nilai pendidikan karakter bagi anak-anak SD usia 6-8 tahun. Oleh karena itu, kiranya perlu untuk memilih acara televisi yang bernilai karakter. Berdasarkan hal tersebut, tujuan penelitian ini untuk menggali nilai-nilai pendidikan karakter dalam acara televisi yang diminati anak-anak SD usia 6-8 tahun.

\section{METODOLOGI}

Pendekatan utama penelitian ini adalah deskriptif kualitatif (Tojo \& Takagi, 2017; Zurqoni, Retnawati, Apino, \& Anazifa, 2019). Pendekatan deskriptif kualitatif dalam penelitian ini digunakan untuk menghasilkan deskripsi data berupa deskripsi nilai-nilai pendidikan karakter yang disajikan dalam program acara yang diminati anak-anak SD usia 68 tahun. Sesuai dengan pendekatan yang digunakan dalam penelitian ini, datanya berupa 
tuturan yang mengandung nilai-nilai pendidikan karakter yang disajikan dalam program acara televisi yang diminati anak-anak SD usia 6-8 tahun. Sumber datanya berupa program acara televisi yang diminati anak-anak SD usia 6-8 tahun.

Sesuai dengan data yang digunakan dalam penelitian ini, data-data penelitian dikumpulkan dengan teknik kuesioner, observasi dan teknik catat. Lokasi penelitian ini dilakukan di desa Hadirejo dan desa Denggungan Boyolali Kuesioner yang dimaksud dalam penelitian ini dilakukan dengan cara memberikan angket kepada anak-anak SD usia 6-8 tahun untuk menjawab beberapa pertanyaan berkaitan dengan program acara yang diminati untuk ditonton setiap hari. Jumlah responden yang digunakan dalam wawancara berjumlah lima belas anak SD usia 6-8 tahun dengan tingkat pendidikan mulai dari kelas satu sampai dengan kelas tigas. Hasil kuesioner ini adalah generalisasi program acara televisi yang diminati anak SD usia 6-8 tahun. Metode observasi dalam penelitian ini dilakukan dengan cara mengamati program acara televisi yang diminati anak-anak SD usia 6-8 tahun secara kritis untuk menemukan gambaran awal nilai-nilai pendidikan karakter yang disajikan dalam program tersebut. Selanjutnya, setelah ditemukan gambaran awal nilai-nilai pendidikan karakter yang disajikan dalam program acara televisi, dilakukan pencatatan nilai-nilai pendidikan karakter sesuai dengan jenisnya.

Analisis data penelitian ini menggunakan metode padan referensial (Sudaryanto, 2015) dan metode padan intralingual (Mahsun, 2014). Kedua metode padan tersebut dalam penelitian ini digunakan untuk memperoleh nilai-nilai pendidikan karakter dalam program acara televisi yang diminati anak-anak SD usia 6-8 tahun. Metode ini dilakukan dengan cara menghubung-hubungkan tanda-tanda bahasa dengan nilai-nilai pendidikan karakter yang terdapat dalam program acara televisi yang diminati anak-anak SD usia 6-8 tahun. Hasil analisis data penelitian ini adalah generalisasi nilai-nilai pendidikan karakter yang terdapat dalam program acara televisi yang diminati anak-anak SD usia 6-8 tahun.

\section{HASIL DAN PEMBAHASAN}

Hasil dan pembahasan dalam penelitian ini menyajikan program acara yang diminati anak-anak SD usia 6-8 tahun yang selanjutnya menyajikan nilai-nilai pendidikan karakter yang disajikan dalam program acara televisi yang diminati anak-anak SD usia 6-8 tahun. Dengan demikian, pada bagian ini akan difokuskan pada program acara yang diminati anakanak SD usia 6-8 tahun dan nilai-nilai pendidikan karakter dalam acara yang diminati anakanak SD usia 6-8 tahun. Lebih lanjut penjelasannya sebagai berikut.

\section{Program Acara yang Diminati Anak Usia 6-8 Tahun}

Program acara televisi yang diminati anak-anak SD kelas rendah usia 6-8 tahun dapat dikategorikan menjadi sembilan program acara. Sembilan program acara televisi yang diminati anak-anak SD usia 6-8 tahun meliputi: (1) SpongeBob, (2) Upin dan Ipin, (3) Kamen Rider, (4) Doraemon, (5) Munkin dan Trunk, (6) Si Bolang, (7) On The Spot, (8) Anak Langit, dan (9) Tukang Ojek Pengkolan. Lebih lanjut disajikan pada tabel 1.

Berdasarkan penyajian data pada tabel 1 menunjukkan acara televisi yang diminati anak-anak SD usia 6-8 tahun bervariasi, yakni sembilan variasi. Kesembilan acara televisi tersebut tentunya memiliki nilai-nilai pendidikan karakter masing-masing. Acara televisi yang paling banyak diminati anak-anak SD usia 6-8 tahun adalah SpongeBob dengan persentase $60 \%$. Alasan anak-anak menyukai acara televisi SpongeBob karena (1) cerita yang disajikan lucu, yakni latar tempat cerita yang ada di dasar laut, (2) ceritanya menarik khususnya pada saat SpongeBob membuat krabi patty, dan (3) ceritanya unik dari segi tokohtokohnya, seperti spons, gurita, bintang laut, kepiting, dan tupai (disarikan dari hasil wawancara dengan Anak SD usia 6-8 tahun pada 27 Oktober 2019).

Program acara televisi yang digemari anak-anak SD usia 6-8 tahun tidak semua memiliki nilai pendidikan karakter yang baik sehingga perlu adanya pendampingan orang 
tua kepada anak dalam hal menonton televisi. Berikut ini disajikan nilai-nilai pendidikan karakter dalam program acara televisi yang digemari anak-anak SD usia 6-8 tahun.

Tabel 1. Acara Televisi yang Diminati Anak-Anak SD Usia 6-8 Tahun

\begin{tabular}{lll}
\hline No & Program Acara Televisi & Persentase \\
\hline 1 & SpongeBob & $60 \%$ \\
2 & Upin dan Ipin & $14 \%$ \\
3 & Kamen Rider & $7 \%$ \\
4 & Doraemon & $4 \%$ \\
5 & Munkin dan Trunk & $3 \%$ \\
6 & Si Bolang & $3 \%$ \\
7 & On The Spot & $3 \%$ \\
8 & Anak Langit & $3 \%$ \\
9 & Tukang Ojek Pengkolan & $3 \%$ \\
\hline & Jumlah & $100 \%$ \\
\hline
\end{tabular}

\section{Nilai Pendidikan Karakter dalam Program Acara Televisi}

Berdasarkan hasil kuesioner berupa acara televisi yang diminati anak-anak SD usia 68 tahun, lalu dianalisis nilai pendidikan karakter yang terdapat dalam acara televisi yang diminati anak-anak SD usia 6-8 tahun. Berdasarkan analisis, nilai-nilai pendidikan karakter pada program acara televisi yang diminati anak-anak SD usia 6-8 tahun dapat dikelompokkan menjadi 10 jenis, meliputi: (1) peduli sosial, (2) kejujuran, (3) cinta damai, (4) nasionalisme, (5) rasa ingin tahu, (6) disiplin, (7) kreatif, (8) kerja keras, (9) tanggung jawab, dan (10) religius. Temuan ini sesuai dengan yang dinyatakan Marinelli (2015) bahwa program acara televisi memiliki nilai-nilai pendidikan. Lebih jelasnya disajikan pada tabel 1.

Tabel 1. Nilai Pendidikan Karakter pada Program Acara yang Diminati Anak SD Usia 6-8 Tahun

\begin{tabular}{|c|c|c|c|c|c|c|c|c|c|c|c|}
\hline No & PA & $\begin{array}{l}\text { Peduli } \\
\text { sosial }\end{array}$ & Jujur & $\begin{array}{l}\text { Cinta } \\
\text { Damai }\end{array}$ & $\begin{array}{l}\text { Nasional- } \\
\text { isme }\end{array}$ & $\begin{array}{l}\text { Rasa } \\
\text { Ingin } \\
\text { tahu }\end{array}$ & Disiplin & Kreatif & $\begin{array}{l}\text { Kerja } \\
\text { keras }\end{array}$ & $\begin{array}{l}\text { Tanggung } \\
\text { Jawab }\end{array}$ & religius \\
\hline 1 & UI & - & - & - & $\sqrt{ }$ & $\sqrt{ }$ & $\sqrt{ }$ & $\sqrt{ }$ & $\sqrt{ }$ & - & - \\
\hline 2 & $S$ & $\sqrt{ }$ & $\sqrt{ }$ & $\sqrt{ }$ & - & - & - & - & - & - & - \\
\hline 3 & KR & $\sqrt{ }$ & - & $\sqrt{ }$ & - & - & - & - & - & - & - \\
\hline 4 & $\mathrm{D}$ & $\sqrt{ }$ & - & - & - & - & - & - & - & $\sqrt{ }$ & - \\
\hline 5 & $\mathrm{MT}$ & $\sqrt{ }$ & - & - & - & - & - & - & - & - & - \\
\hline 6 & SB & $\sqrt{ }$ & - & - & - & - & - & $\sqrt{ }$ & - & - & - \\
\hline 7 & OTS & - & - & - & - & $\sqrt{ }$ & - & - & - & - & - \\
\hline 8 & $\mathrm{AL}$ & $\sqrt{ }$ & - & - & - & - & $\sqrt{ }$ & - & - & - & $\sqrt{ }$ \\
\hline 9 & TOP & $\sqrt{ }$ & - & - & - & - & - & - & - & - & $\sqrt{ }$ \\
\hline
\end{tabular}

Keterangan

$\begin{array}{llll}\text { PA } & \text { : Program Acara } & \text { UI } & \text { : Upin dan Ipin } \\ \text { S } & \text { : SpongeBob } & \text { KR } & \text { : Kamen Rider } \\ \text { D } & \text { : Doraemon } & \text { MT } & \text { : Mungkin and Trunk } \\ \text { SB } & \text { : Si Bolang } & \text { OTS } & \text { : On The Spot } \\ \text { AL } & \text { : Anak Langit } & \text { TOP } & \text { : Tukang Ojek Pengkolan }\end{array}$

\section{Karakter Peduli Sosial}

Program acara televisi yang menyajikan nilai pendidikan karakter peduli sosial adalah: (1) SpongeBob, (2) Kamen Rider, (3) Doraemon, (4) Munkin dan Trunk, (5) Si Bolang, (6) Anak Langit, dan (7) Tukang Ojek Pengkolan. Berikut ini contoh karakter peduli sosial.

(1) Plankton : Hai, Krab...kau menghilangkan sesuatu?

Tuan Krab: Hahhh kumpulan krabby pattyku.

Plankton : "Itu benar Krab. Tidak dapat dipercaya, aku menemukannya tergeletak di bawah. Ahahahaha jadi aku kembalikan. Ini ambillah." (Plankton) (21-12-2019) 
DOI: 10.31004/obsesi.v6i1.875

Contoh (1) merupakan kutipan dialog antara Plankton dengan Tuan Krab dalam program acara SpongeBob. Kepedulian sosial tampak pada respons Plankton yang menemukan benda milik Tuan Krab yang jatuh sehingga Plankton mengambilnya yang kemudian mengembalikan kepada pemiliknya. Karakter kepedulian sosial yang utama tampak pada kepedulian terhadap orang lain atau masyarakat (Ilmi, 2015). Hal ini terlihat dari dialog yang disajikan pada contoh tersebut. Contoh lain juga terdapat pada program acara Kamen Rider berikut;

(2) "Memangnya ada pasien yang tidak boleh ditolong? Seberapa jahatnya orang, nyawa adalah nyawa. Aku tidak akan bisa membiarkan ada pasien kesakitan sementara aku diam saja. Aku tidak akan bisa." (Еmu) (19-12-2019)

Contoh (2) merupakan sikap yang ditunjukkan Emu sebagai perwujudan karakter peduli sosial kepada orang lain. Hal tersebut sesuai dengan yang dinyatakan Purnomo (2016) perwujudan karakter peduli sosial melalui sikap dan tindakan yang selalu ingin memberi bantuan dan pertolongan kepada orang lain. Bantuan yang diberikan Emo adalah dengan mengomunikasikan kepada rumah sakit supaya pasien yang terabaikan dapat segera ditangani. Karakter kepedulian juga terlihat pada program acara Doraemon sebagai berikut.

(3) "Nobita, kami juga akan membantumu mencarinya. Kalau teman kesulitan, kita harus membantunya kan?" (Shizuka) (22-19-2019)

Contoh (3) merupakan sikap kepedulian yang ditampilkan Shizuka pada adalah akan membantu Nobita untuk mencari anjingnya yang hilang. Dengan demikian, sikap dan tindakan yang diungkapkan Shizuka termasuk karakter kepedulian sosial kepada Nobita dalam mencari anjing. Contoh karakter peduli sosial lainnya sebagai berikut.

(4) "Tanaman anggrek yang layu itu pun lalu dibawa Trunk ke lebah. Oleh lebah, tanaman itu ditaruh di tepi sungai dan usahanya berbuah manis, tanaman anggrek itu bisa hidup." (24-10-2019)

Contoh (4) merupakan perilaku yang menunjukkan karakter kepedulian. Perilaku tersebut terlihat ketika Trunk membantu Munki dengan cara membawa tanaman anggrek yang layu dan diberikan kepada lebah dan lebah pun membawa tanaman anggrek yang layu ke tepi sungai dan akhirnya tanaman anggrek menjadi hidup kembali. Hal tersebut dapat dijadikan sebagai media pendidikan karakter. Hal ini sesuai dengan konten pendidikan yang sering mengangkat permasalahan lingkungan (Feszterova \& Jomova, 2015). Program acara televisi yang menyajikan karakter peduli sosial selanjutnya adalah Si Bolang berikut contohnya.

(5) "Setelah ini, kami akan membantu ibu membuat ramuan supaya ikan segar dan tahan lama. Ayooo, cepat, ibu sudah menunggu." (19-12-2019)

Contoh (5) merupakan aktivitas yang menunjukkan karakter peduli sosial, yakni membantu orang tua membuat ramuan supaya ikan tetap Segar dan tahan lama. Membantu orang tua atau orang yang lebih tua merupakan perwujudan karakter kepedulian sosial. Berikut ini program acara televisi yang menyajikan nilai pendidikan karakter peduli sosial.

(6) "Alamaak...pojam ini pojam my endless lope. Tak akan ku biarkan ini my endless lope. Kalau gitu kita harus kasih pertolongan pertama. Kita susulin kakak kembaranku naek motor sekalian refreshing ayo." (Cantika) (19-12-2019)

Contoh (6) karakter kepedulian dalam program acara tersebut ditampilkan dengan bentuk kepedulian seorang tokoh untuk menolong tokoh lain yang sedang mengalami kesulitan dan membutuhkan pertolongan. Oleh karena itu sikap tolong-menolong perlu diteladani (Normawati, 2015). Tindakan tersebut dapat dikategorikan sebagai perwujudan karakter kepedulian sosial. Program acara televisi yang selanjutnya menyajikan karakter kepedulian sosial adalah acara TOP.

(7) "Saya kan baru pulang dari warung. Tadi sih nggak mati lampu, nggak tahu sekarang. Sebentar, saya cek dulu ya." (Tetangga Oliv) (18-12-2019) 
Contoh (7) menggambarkan karakter peduli sosial yang terlihat dari sikap tetangga Oliv yang membantunya untuk melihat apakah terjadi pemadaman listrik atau tidak. Hal tersebut menunjukkan betapa pentingnya untuk bergandeng tangan dengan tujuan saling menguatkan, menyemangati, dan menasihati (Octaviana, 2018).

\section{Karakter Kejujuran}

Karakter kejujuran termasuk dalam karakter inti yang sangat penting ditumbuhkan kepada anak-anak sebagai calon pemimpin bangsa. Salah satu perwujudan karakter kejujuran adalah antikorupsi (Relin et al., 2018). Karakter jujur dalam program acara televisi yang diminati anak-anak SD usia 6-8 tahun terdapat dalam program acara Spoengebob. Berikut ini disajikan contoh tuturan yang menunjukkan karakter kejujuran dalam program acara televisi yang diminati anak-anak SD usia 6-8 tahun.

(8) "Itu benar Krab. Tidak dapat dipercaya, aku menemukannya tergeletak di bawah. Ahahahaha jadi aku kembalikan. Ini ambilah." (Plankton) (21-12-2019)

Contoh (8) merupakan penggambaran karakter kejujuran yang dilakukan oleh Plankton dalam program acara televisi SpongeBob. Karakter kejujuran tampak pada sikap Planton yang menemukan barang yang hilang, yakni resep Kraby Patty kemudian mengembalikan kepada pemiliknya, yakni Tuan Krab. Mengembalikan barang yang ditemukan bukan milik kita kepada pemiliknya merupakan perwujudan karakter kejujuran. Karakter kejujuran dalam berbagai budaya sangat dijunjung tinggi, salah satunya dalam budaya Jawa terdapat sebuah pemeo "Daripada hidup bercermin bangkai lebih baik mati berkalang tanah". Betapa tingginya karakter untuk menjaga harga diri dan kejujuran (Adhani, 2016). Oleh karena itu karakter kejujuran, sopan santun, kerja keras dan berbagai karakter yang baik harus dipertahankan terutama melalui pendidikan formal, yakni sekolah (Kusdaryani et al., 2016).

\section{Karakter Cinta Damai}

Cinta damai merupakan karakter yang ditunjukkan dengan sikap dan perilaku yang menyukai adanya harmoni dan bebas konflik dan gangguan, suka akan ketenangan. Melalui karakter cinta damai ini akan terwujud sikap dan tindakan yang mendorong seseorang untuk memberikan kebermanfaatan bagi orang lain, mengakui, dan menghormati hasil karya orang lain (Wandasari, 2017). Berikut ini program acara televisi yang menyajikan nilai pendidikan karakter cinta damai.

(9) "Tuan Krab, aku rasa Plankton benar-benar berubah. Dia hanya membutuhkan sedikit dorongan dan aku tahu bagaimana melakukannya." (SpongeBob) (21-19-2019)

Contoh (9) Sikap yang ditunjukkan SpongeBob merupakan perwujudan karakter cinta damai, sebuah pepatah mengatakan bahwa musuh satu itu banyak teman seribu itu sedikit. Maksudnya dalam kehidupan seseorang hendaknya mencari teman yang sebanyakbanyaknya dan tidak memiliki musuh satu pun. Karakter cinta damai merupakan salah satu dari sembilan karakter yang harus dimiliki siswa (Agustian \& Arnida, 2018). Program acara televisi selanjutnya yang menyajikan nilai pendidikan karakter cinta damai adalah Kamen Rider.

(10) "Heyy kau jangan galak seperti ini. Waktu itu aku salah padamu. Dan sebagai permintaan maaf dariku, aku akan memberi tahu informasi yang sudah kudengar. Dengar aku...Aku melihat sosok kamen rider yang sangat misterius." (Kiriya) (19-12-2019)

Contoh (10) menunjukkan sikap karakter cinta damai, yakni Kiriya yang mengakui kesalahan dan meminta maaf serta berdamai dengannya. Sikap yang demikian dalam diri anak-anak perlu ditumbuhkembangkan sebagai upaya minimalisasi tawuran yang selama ini dilakukan pelajar. Dengan demikian, akan terwujud suasana damai, aman, tenang, dan nyaman atas kehadiran dirinya dalam komunitas masyarakat tertentu (Nugroho, 2018). 
DOI: 10.31004 /obsesi.v6i1.875

\section{Karakter Cinta Tanah Air}

Karakter cinta tanah air harus dimiliki oleh seriap warga negara. Hal tersebut dapat terimplementasi dalam kehidupan manakala pendidikan karakter cinta tanah air dilakukan sejak kecil, salah satunya melalui lembaga pendidikan (Aprilina, Fauziah, \& Affan, 2017; Atika, Wakhuyudin, \& Fajriyah, 2019; Hartanto, 2019). Adapun program acara televisi yang diminati anak-anak SD usia 6-8 tahun adalah Upin dan Ipin.

(11) "Dia bukan sekadar buah. Tapi program konsumsi buah lokal adalah budaya masyarakat kita yang harus dilestarikan." (Bu Guru) (21-12-2019)

Contoh (11) merupakan gambaran karakter cinta tanah air, yakni nasihat Bu Guru kepada murid-muridnya untuk melestarikan budaya konsumsi buah-buah lokal yang dimiliki suatu negara. Mengonsumsi buah-buahan yang dihasilkan bangsa sendiri merupakan bentuk karakter cinta tanah air (Setiawaty et al., 2018). Karakter cinta tanah air dalam diri siswa perlu ditumbuhkembangkan dalam diri siswa. Hal tersebut diperlukan karena pada abad ke-21 problematik pendidikan cinta tanah air adalah mengikisnya rasa cinta tanah air warga negara (Ikhsan, 2017).

\section{Karakter Rasa Ingin Tahu}

Karakter rasa ingin tahu dalam diri seseorang diwujudkan dengan keinginan untuk menyelidiki dan mencari pemahaman terhadap rahasia alam atau peristiwa sosial yang sedang terjadi. Generasi millennial memiliki rasa ingin tahu yang lebih banyak akan informasi dan berbagai peristiwa (Fahrimal, 2018). Program acara televisi yang menyajikan karakter rasa ingin tahu di antaranya adalah: Upin dan Ipin dan On The Spot.

(12) Opah : “Benar, Ros... Berikan pisang pada adik-adikmu. Agar mereka kuat .. dan makan buah bisa meningkatkan sistem imunisasi."

Upin : "Hah... Apa artinya?" (21-12-2019)

Contoh (12) merupakan bentuk karakter rasa ingin tahu Upin akan informasi yang telah disampaikan oleh neneknya. Adapun informasi sebelumnya yang disampaikan Opah adalah memakan buah-buah dapat meningkatkan imunitas. Kata imunitas tersebut yang mendorong Upin untuk mengetahui lebih lanjut dengan meminta penjelasan kepada Opah. Hal tersebut merupakan perwujudan karakter rasa ingin tahu, yakni berupaya mengetahui apa yang dipelajari, dilihat, dan didengar (Anwar et al., 2017).

(13) "Benarkah seseorang yang sudah meninggal masih bisa melahirkan seorang bayi?" (19-12-2019)

Contoh (13) memiliki nilai pendidikan karakter rasa ingin tahu. Hal ini tampak pada ungkapan yang disajikan dalam narasi tersebut yang merangsang penonton acara tersebut untuk mengetahui lebih lanjut terhadap pernyataan yang disampaikan, yakni Benarkah seseorang yang sudah meninggal masih bisa melahirkan seorang bayi? Pernyataan demikian akan merangsang penonton untuk ingin tahu lebih lanjut, dengan demikian hal tersebut akan merangsang karakter rasa ingin tahu. Melalui karakter rasa ingin tahu diharapkan siswa dapat mencapai kompetensi dalam pendidikan (Khoiron \& Sutadji, 2015).

\section{Karakter Kedisiplinan}

Karakter kedisiplinan ialah sikap dan perilaku yang muncul karena pelatihan atau kebiasaan menaati aturan, hukum atau perintah. Oleh karena itu, karakter disiplin ini membutuhkan proses, tidak dapat ditanamkan kepada diri secara tiba-tiba. Program acara televisi yang menyajikan nilai-nilai pendidikan karakter kedisiplinan meliputi: Upin dan Ipin dan Anak Langit.

(14) "Ibu Guru suka melihat Mail pandai berdagang, tapi kalau mau berdagang buah lokal bukan di sini. Buka warung..." (Bu Guru) (21-19-2019) 
Contoh (14) merupakan tuturan Bu Guru yang mengandung nilai pendidikan karakter disiplin, yakni Bu Guru mengingatkan kepada Mail mengenai tata tertib di sekolah tidak boleh berjualan di kelas. Nilai pendidikan karakter disiplin dalam program acara Upin dan Ipin juga terlihat ketika Upin menyuruh Ipin untuk bergegas memakai sepatu karena telah ditunggu kak Ros untuk berangkat sekolah (Untari \& Purnomo, 2016). Nilai pendidikan karakter kedisiplinan juga terdapat dalam program acara televisi Anak Langit.

(15) “Walaupun kita buru-buru. Kita harus tertib lalu lintas ya." (Gerry) (19-12-2019)

Contoh (15) merupakan tuturan yang memiliki nilai-nilai pendidikan karakter kedisiplinan. Kedisiplinan tersebut diwujudkan dengan tertib berlalu lintas meskipun dalam keadaan buru-buru harus tetap memperhatikan keselamatan. Sikap disiplin dalam program acara tersebut dilakukan dengan kerelaan hati tanpa adanya paksaan.

\section{Karakter Kreatif}

Kreativitas merupakan karakter yang diwujudkan dengan melaksanakan pemenuhan kebutuhan, berorientasi penyelesaian tugas, atau perwujudan gagasan dengan perspektif yang baru. Karakter kreatif dalam diri anak-anak perlu dikembangkan supaya terjadinya berbagai inovasi. Program acara yang menyajikan nilai karakter kreatif adalah Upin dan Ipin dan Si Bolang.

(16) "Ee jangan semua daun itu bisa dijadikan lidi. Ha (membuat sapu lidi dari daun yang kecoklatan) taraa... jadi sapu lidi." (Tok Dalang) (21-12-2019)

Contoh (16) kreativitas yang disajikan pada contoh tersebut adalah mengubah daun kelapa menjadi sepatu lidi. Hal tersebut dipandang kreatif karena biasanya daun dan lidi pohon kelapa dimanfaatkan menjadi sapu. Berdasarkan hal tersebut menunjukkan nilai kebaruan atau kreativitas. Program acara yang selanjutnya menyajikan nilai pendidikan karakter kreativitas adalah Si Bolang.

(17) "Naah buah kelor tadi akan dijadikan ramuan untuk mengawetkan ikan, teman. Tapi, pertama, kita cuci dulu ikan-ikannya yaa. Tangkapan ikan sebanyak ini tidak akan habis dalam sehari, jadi sebagian harus diawetkan. Selain dikeringkan dan diasinkan, ada cara lain untuk mengawetkan ikan secara alami, yaitu menggunakan ramuan daun kelor. Tumbuk daun kelor perlahan hingga halus. Selanjutnya, masukkan tumbukan kelor ke dalam wadah berisi air. Kemudian, remas-remas untuk mengeluarkan sari-sarinya." (19-12-2019)

Contoh data (17) tersebut menunjukkan nilai pendidikan karakter kreativitas yang dilakukan oleh Bolang dan teman-temannya, yakni memanfaatkan buah kelor sebagai ramuan untuk mengawetkan ikan. Cara tersebut dapat dinyatakan kreatif karena dalam mengawetkan ikan biasanya menggunakan garam. Kreativitas tersebut tentunya juga dapat dilakukan di tempat lain yang memang tidak banyak tersedia garam, namun dapat ditemukan daun kelor.

\section{Karakter Kerja Keras}

Karakter kerja keras terwujud dalam bekerja dengan penuh kegairahan, semangat yang meluap-luap, rajin, dan tekun. Karakter kerja keras dalam diri anak-anak perlu ditumbuhkembangkan mengingat persaingan global yang semakin kompetitif. Program acara televisi yang menyajikan nilai pendidikan karakter kerja keras adalah Upin dan Ipin.

(18) "Kalian pandai sekali. Tidak percuma liburan kalian. Masih kecil sudah pandai berdagang, nenek suka semangat kalian." (Opah) (21-12-2019)

Contoh (18) menunjukkan karakter kerja keras yang dilakukan Upin dan Ipin dengan memanfaatkan waktu liburan sekolah untuk bekerja dengan berjualan. Hal terebut menunjukkan karakter kerja keras, biasanya anak-anak yang masih pada usia sekolah menghabiskan waktu berlibur untuk bermain namun berbeda dengan Upin dan Ipin waktu liburannya mereka gunakan untuk berjualan. 
DOI: $10.31004 /$ obsesi.v6i1.875

\section{Karakter Tanggung Jawab}

Karakter tanggung jawab merupakan karakter utama yang seharusnya dimiliki oleh setiap orang, termasuk anak-anak. Tanggung jawab merupakan perwujudan akan kewajiban yang harus dikerjakan (Rochmah, 2016). Program acara yang menyajikan nilai pendidikan karakter tanggung jawab adalah Doraemon.

(19) Nobita : Huuh huuuh....kalau punya barang baru selalu saja pamer ke orang lain. (menendang sesuatu)

Giant : Whuaaa.....

Nobita :"Aaaa...maaf aku tidak sengaja."(22-12-2019)

Contoh (19) menunjukkan karakter tanggung jawab, yakni sikap Nobita yang melakukan kesalahan kepada Giant dan segera bertanggung jawab dengan meminta maaf kepada Giant. Sikap yang demikian merupakan perwujudan karakter tanggung jawab. Pembentukan karakter tanggung jawab dalam diri anak-anak sangat dipengaruhi oleh faktor lingkungan (Faradiba \& Royanto, 2018). Lingkungan yang dimaksud adalah lingkungan keluarga, sekolah, dan lingkungan masyarakat.

\section{Karakter Religius}

Religius dalam diri anak-anak perlu ditumbuhkembangkan. Pendidikan karakter yang berlandaskan pada ajaran religi, maka esensinya mengarah ke humanisme religius (Widodo, 2018). Bahkan dalam Islam anak sejak usia dini harus diberi pelajaran tentang agama. Program acara televisi yang menyajikan nilai pendidikan karakter religius adalah Anak Langit dan TOP.

(20) “Asalamualaikum" (Jay) (19-12-2019)

Contoh (20) menujukkan karakter religius, yakni memberikan salam kepada mitra wicara dalam berkomunikasi sebagai doa keselamatan untuk mitra wicara. Memberikan salam merupakan perwujudan karakter religius. Karakter religius dengan memberikan salam juga terlihat pada program acara TOP.

(21) “Asalamualaikum pak haji." (Emak) (18-12-2019)

Contoh (21) merupakan salam yang disampaikan oleh tokoh Emak kepada Pak Haji dalam program acara TOP. Karakter tersebut perlu ditumbuhkembangkan kepada anak-anak SD usia 6-8 tahun karena generasi kekinian silau akan budaya luar yang belum tentu membumi dan memiliki nilai religius (Santoso et al., 2018).

\section{SIMPULAN}

Berdasarkan hasil dan pembahasan yang telah disajikan di atas, maka dapat disimpulkan nilai-nilai pendidikan karakter yang terdapat dalam program acara televisi yang diminati anak-anak SD usia 6-8 tahun dapat diklasifikasikan menjadi sepuluh nilai karakter. Hal tersebut menunjukkan program acara yang diminati anak-anak memiliki nilai pendidikan karakter dan potensial dijadikan sebagai media sosialisasi nilai pendidikan karakter dengan memperhatikan tingkat perkembangan anak-anak SD usia 6-8 tahun. Adapun dari sepuluh program acara televisi yang diminati anak-anak SD usia 6-8 tahun, hanya tiga yang relevan untuk anak SD usia 6-8 tahun, yakni (1) Upin dan Ipin, (2) Munkin and Trum, dan (3) Si Bolang.

\section{UCAPAN TERIMA KASIH}

Terima kasih kepada Ketua Lembaga Penelitian dan Pengabdian Masyarakat (LPPM), Universitas Muhammadiyah Surakarta (UMS) yang telah memilih proposal Penelitian Unggulan Program Studi untuk didanai. Kepada semua pihak yang telah membantu sehingga artikel ini dapat dipublikasikan. 


\section{DAFTAR PUSTAKA}

Adhani, A. (2016). Peribahasa, maknanya, dan sumbangannya terhadap pendidikan karakter. Magistra, XXVIII(97), 97-110.

Agustian, \& Arnida. (2018). Analisis Karakter Cinta Damai dalam Pembelajaran IPA di Lingkungan Belajar SMP Negeri 17 Kota Jambi. Science Education Journal (SEJ), 2(1), 1-13. https:// doi.org/10.21070/sej.v2i1.2109

Akbar, S., Samawi, A., Arafiq, M., \& Hidayah, L. (2014). Model Pendidikan Karakter yang Baik di SD (Studi Lintas Situs Best Practices). Jurnal Sekolah Dasar Kajian Teori Dan Praktik Pendidikan, 2(2), 139-151.

Andrianto, N. (2018). Pesan Kreatif Iklan Televisi dalam Bulan Ramadan: Analisis Semiotika Iklan Bahagianya adalah Bahagiaku. Jurnal Studi Komunikasi (Indonesian Journal of Communications Studies), 2(1), 17-31. https://doi.org/10.25139/jsk.v2i1.336

Anwar, S., Noviyanti, N., \& Hendrawan, H. (2017). Analisis Kelayakan Buku Teks Kimia SMA/MA Kelas X Materi Reaksi Redoks Berdasarkan Kriteria Tahap Seleksi 4S TMD. Jurnal Penelitian Pendidikan Kimia : Kajian Hasil Penelitian Pendidikan Kimia, 4(2), 97--104.

Aprilina, N., Fauziah, T., \& Affan, M. H. (2017). Implementasi Pendidikan Karakter Cinta Tanah Air melalui Pembelajaran IPS di Gugus 25 SDN 2 Mata IE Aceh Besar. Jurnal Ilmiah Pendidikan Guru Sekolah Dasar, 2(3), 32-40. https:// doi.org/10.1017/CBO9781107415324.004

Atika, N. T., Wakhuyudin, H., \& Fajriyah, K. (2019). Pelaksanaan Penguatan Pendidikan Karakter Membentuk Karakter Cinta Tanah Air. Mimbar Ilmu, 24(1), 105-113. https:// doi.org/10.23887/mi.v24i1.17467

Darmastuti, R., Purnomo, J. T., Utami, B. S., \& Yulia, H. (2019). Literasi Media Berbasis Kearifan Lokal Masyarakat Bali. Jurnal Studi Komunikasi (Indonesian Journal of Communications Studies), 3(3), 402. https:// doi.org/10.25139/jsk.v3i3.1538

Fahrimal, Y. (2018). Netiquette: Etika Jejaring Sosial Generasi Milenial dalam Media Sosial. Penelitian Pers Dan Komunikasi Pembangunan, 22(1), 69-78. https:// doi.org/10.46426/jp2kp.v22i1.82

Faradiba, A. T., \& Royanto, L. R. M. (2018). Karakter Disiplin , Penghargaan, dan Tanggung Jawab dalam Kegiatan Ekstrakurikuler. Jurnal Sains Psikologi, 7(1), 93-98.

Feszterova, M., \& Jomova, K. (2015). Character of Innovations in Environmental Education. Procedia-Social and Behavioral Sciences, 197(February), 1697-1702. https:// doi.org/10.1016/j.sbspro.2015.07.222

Hartanto, S. (2019). Manajemen Pendidikan k Karakter Cinta Tanah Air (Analisis Konseptual Peran Kepala Sekolah dan Guru). Wahana Islamika: Jurnal Studi Keislaman, 5(2), 4965.

Ikhsan, M. A. (2017). Nilai-Nilai Cinta Tanah Air dalam Perspektif Al-Qur'an. Jurnal Ilmiah Pendidikan Pancasila Dan Kewarganegaraan, 2(2), 108-114. https:// doi.org/10.17977/um019v2i22017p108

Ilmi, D. (2015). Pendidikan Karakter Berbasis Nilai-nilai Kearifan Lokal melalui Ungkapan Bijak Minangkabau. ISLAM REALITAS: Journal of Islamic \& Social Studies Vol., 1(1), 45-54.

Khoiron, A. M., \& Sutadji, E. (2015). Kontribusi Implementasi Pendidikan Karakter dan Lingkungan Sekolah terhadap Berpikir Kreatif serta Dampaknya pada Kompetensi Kejuruan. Jurnal Pendidikan Dan Pembelajaran, 22(2), 103-116.

Kostyrka-Allchorne, K., Cooper, N. R., \& Simpson, A. (2017). The relationship between television exposure and children's cognition and behaviour: A systematic review. Developmental Review, 44, 19-58. https://doi.org/10.1016/j.dr.2016.12.002

Kusdaryani, W., Purnamasari, L., \& Damayani, A. T. (2016). Penguatan Kultur Sekolah untuk Mewujudkan Pendidikan Ramah Anak. Cakrawala Pendidikan, XXX(1), 125-133. https://doi.org/10.21831/cp.v1i1.8383 
Kusuma, G. G., \& Darmastuti, R. (2019). Strategi Public Relations melalui Acara Sitcom OKJEK di NET TV. Jurnal Studi Komunikasi (Indonesian Journal of Communications Studies), 3(1), 68. https:// doi.org/10.25139/jsk.v3i1.1427

Lin, L. Y., Cherng, R. J., Chen, Y. J., Chen, Y. J., \& Yang, H. M. (2015). Effects of television exposure on developmental skills among young children. Infant Behavior and Development, 38, 20-26. https:// doi.org/10.1016/j.infbeh.2014.12.005

Mahsun, M. S. (2014). Metode Penelitian Bahasa Metode Penelitian Bahasa: Tahapan Strategi Metode dan Tekniknya. Raja Grafindo Persada.

Marinelli, M. (2015). Impact of television on the quality of sleep in preschool children. Sleep Medicine, 10-11. https://doi.org/10.1016/j.sleep.2015.07.011

McAnally, H. M., Young, T., \& Hancox, R. J. (2019). Childhood and adolescent television viewing and internalising disorders in adulthood. Preventive Medicine Reports, 15(May), 1-5. https:// doi.org/10.1016/j.pmedr.2019.100890

Normawati. (2015). Nilai Pendidikan Karakter dalam Buku Teks Pelajaran Bahasa Indonesia SMP di Daerah Istimewa Yogyakarta. Jurnal Pendidikan Karakter, V(1), 48-69. https://doi.org/10.21831/jpk.v0i1.8612

Novita, A., Hamid, solihin I., \& Rustini, T. (2017). Studi Dampak Tayangan Televisi terhadap Perkembangan Perilaku Sosial Anak. Cakrawala Dini Jurnal Pendidikan Anak Usia Dini, 8(1), 1689-1699. https:// doi.org/10.1017/CBO9781107415324.004

Nugroho, R. (2018). Kebijakan Membangun Karakter Bangsa. Elex Media Komputindo.

Octaviana, D. W. (2018). Analisis Nilai-Nilai Pendidikan dalam Novel Uhibbuka Fillah (Aku Mencintaimu karena Allah) Karya Ririn Rahayu Astuti Ningrum: Kajian Sosiologi Sastra. Jurnal KATA, 2(2), 182. https:// doi.org/10.22216/jk.v2i2.3334

Purnomo, F. S. (2016). Analisis Nilai-Nilai Pendidikan Karakter dalam Film Upin dan Ipin Produksi Les Copaque Tahun 2010. Diksa : Pendidikan Bahasa Dan Sastra Indonesia, 2(2), 142-149. https:// doi.org/10.33369/diksa.v2i2.3411

Relin, R., Rasna, I. W., \& Binawati, W. S. (2018). Values Implied in the Wratisasana Palm Manuscripts as Guideline of Politeness in Language of the Character Education: A Study of Theo-Ethno Pedagogy. Journal of Language Teaching and Research, 9(1), 90. https://doi.org/10.17507/jltr.0901.11

Rochmah, E. Y. (2016). Mengembangkan Karakter Tanggung Jawab pada Pembelajaran (Perspektif Psikologi Barat dan Psikologi Islam). Al Murabi, 3(1), 36-54.

Rohani, G. A. (2017). Pengaruh Televisi (TV) terhadap Aspek-Aspek Perkembangan Anak Usia 3-4 Tahun. Jurnal Pendidikan Anak, 4(2). https://doi.org/10.21831/jpa.v4i2.12355

Sabakti, S. (2018). Konsep Pendidikan Karakter dalam Buku Pandangan Orang Melayu terhadap Anak Karya Tenas Effendy. Widyaparwa, 46(2), 189-204. https://doi.org/10.26499/wdprw.v46i2.193

Samani, M., \& Hariyanto. (2017). Konsep dan Model Pendidikan Karakter. PT Remaja Rosdakarya.

Santoso, J., Sabardila, A., Wahyudi, A., Setiawaty, R., \& Kusmanto, H. (2018). Membangun Karakter Siswa Sekolah Dasar melalui Media Ungkapan Hikmah. Prosiding Seminar Nasional Al-Islam Dan Kemuhammadiyahan, 65-75.

Sari, A. L., Nariyah, H., \& Wihayati, W. (2019). Studi Fenomenologi Film Animasi Upin dan Ipin di MNC TV dalam Membentuk Perilaku Imitasi pada Anak di TK Al-Muhibbin Kecamatan Sumber Kabupaten Cirebon. Jurnal Signal, 7(1), 15-26. https://doi.org/10.33603/signal.v7i1.1915

Setiawaty, R., Wahyudi, A. B., Santoso, J., Sabardila, A., \& Kusmanto, H. (2018). Stiker Ungkapan Hikmah sebagai Media Pemartabatan Karakter Anak Didik di Lingkungan Sekolah Muhammadiyah. L-Islam Dan Kemuhammadiyahan Multiprespektif, 177-188.

Sudaryanto. (2015). Metode dan Aneka Teknik Analisis Bahasa Pengantar Penelitian Wahana Kebudayaan secara Linguistis. Sanata Dharma University Press. 
Suryanto, E. (2017). Pengembangan Materi Ajar Mata Kuliah Apresiasi Drama melalui Penggalian Nilai-Nilai Pendidikan Karakter Naskah Drama Panembahan Reso Karya W.S. Rendra. Bahasa Dan Seni: Jurnal Bahasa, Sastra, Seni Dan Pengajarannya, 44(2), 207-223. https://doi.org/10.17977/um015v44i22016p207

Tarigan, T., Ervani, N., \& Lubis, S. (2016). Pola Menonton Televisi dan Pengaruhnya terhadap Anak. Sari Pediatri, 9(1), 44. https:// doi.org/10.14238/sp9.1.2007.44-7

Tojo, H., \& Takagi, A. (2017). Trends in Qualitative Research in Three Major Language Teaching and Learning Journals, 2006-2015. International Journal of English Language Teaching, 4(1), 37. https:// doi.org/10.5430/ijelt.v4n1p37

Untari, M. F. A., \& Purnomo, F. U. (2016). Kajian Nilai Moral dalam Film Kartun Upin dan Ipin Edisi "Ikhlas dari Hati" Produksi Les' Copaque. Malih Peddas (Majalah Ilmiah Pendidikan Dasar), 6(1), 9-18. https://doi.org/10.26877/malihpeddas.v6i1.1113

Wandasari, Y. (2017). Implementasi Gerakan Literasi Sekolah (GLS) sebagai Pembentukan Pendidikan Berkarakter. JMKSP Jurnal Manajemen, Kepemimpinan, Dan Supervisi Pendidikan, 1(1), 325-343. https:// doi.org/10.31851/jmksp.v2i2.1480 